\title{
Floristic Composition, Structural Analysis and Regeneration Status of Woody Species of Natural Forest in Gemechis District of West Hararghe Zone, Oromia, Ethiopia
}

\author{
Sudi Dawud $^{1} \quad$ Meseret Chimdessa $^{2} \quad$ J.M.Sasikumar ${ }^{3}$ \\ 1. Mechara Agricultural Research Center, Oromia Agricultural Research Institute, , PO box 19 \\ 2. School of Biology and Biotechnology, College of Natural and Computational Sciences, Haramaya University, \\ Haramaya, PO box, 138
}

\begin{abstract}
The study was conducted on Gemechis natural forest, West Hararghe, Oromia Regional state, Ethiopia with the objective of determining the floristic composition, structural analysis and regeneration of wood plant species. Systematic sampling was used to collect vegetation data. Accordingly,50 sampling quadrats of $20 \mathrm{~m} \times 20 \mathrm{~m}$ were laid along six line transects at every $50 \mathrm{~m}$ interval within which five $5 \mathrm{mx} 5 \mathrm{~m}$ small quadrats were laied to sample woody species with $<2 \mathrm{~cm}$ DBH (diameter at breast height). In each quadrat, all live woody species were recorded with their number counted and $\mathrm{DBH}$ measured for those with $\mathrm{DBH}>2 \mathrm{~cm}$. Fifty one (51) woody species belonging to 50 genera and 34 families were recorded in the forest. The collected specimens were composed of $64.7 \%$ of tree, $31.3 \%$ shrubs and $3.9 \%$ of lianas. The most species rich families were Rosaceae, Lamiaceae and Myrsinaceae. Shannon diversity index and evenness of woody species of the Gemechis natural forest were 3.04 and 0.77 , respectively. The total density of woody species recorded in Gemechis forest was 3430 individuals ha $^{-}$ ${ }^{1}$. Total basal area of woody species in the study area was $31.12 \mathrm{~m}^{2} \mathrm{~h}^{-1}$. The dominant and ecologically most important tree species in Gemechis Forest on the basis of their importance value index( IVI) values were Maesa lanceolata (19.2), Rytigna neglecta (16.9), Maytenus sp. (15.9), Bersama abyssinica (14.2), Argomuellera macrophyllab (11.7), Dovyalis caffra (10.9), Teclea nobilis (9.24) and Vernonia amygdalina (7.3). Cummulative DBH class distribution showed that large number of individuals fall in lower DBH class, which shows that this vegetations is in a good regeneration status. However, as some species are of irregular population structure and low IVI further study should be conducted to identify factors that negatively affect them. In general, the data from this study showed that the forest had high species diversity. From the cummulative DBH class distribution of the study area, the number of individuals that fall in lower DBH classes were higher than their number at higher DBH classes which indicate that seedlings and sapling were more in number than the mature/older woody species which suggesting that vegetation of Gemechis forest was generally in a good regeneration status.
\end{abstract}

Keywords: Basal area, Diameter at breast highest, Gemechis forest, Important value index, Woody species DOI: $10.7176 / \mathrm{JBAH} / 9-1-07$

\section{Introduction}

Globally, about 30 percent of the land is covered by forests which account about 3952 million hectares (FAO, 2007). Forests worldwide are known to be critically important habitats for the biodiversity they contain and for the ecological functions they serve (Pearce, 2001). People living in or around forests depend on the forests for many forest products and environmental services. However, gradually the coverage of forest is declining due to deforestation, which is taking place at rate of 12.9 million ha/year mainly as a result of conversion of forests to agricultural land, expansion of human settlements, and utilization of forests for infrastructure (FAO, 2007). Africa has 675 million hectares of forest and 350 million hectares of wooded land which together cover 35 per cent of its total land area (FAO, 2010). This includes tropical moist forests primarily in Central and West Africa, tropical dry forest, mostly in East and Southern Africa, including the miombo woodlands in Tanzania and Mozambique, and Mediterranean forests and woodland in North Africa. Especially the most diversified plant species was found in East African Mountains. Tropical Montane Forests are well known among the most hot spot ecosystems on earth. This diversified ecosystem is under severe condition because they are highly suitable for agricultural purposes (Rodrigues et al., 2004).

Ethiopia is found in the Horn of Africa and located between $3^{0} 24$, and $14^{0} 53^{\prime}$ North and $32^{0} 42^{\prime}$ and $48^{0} 12$ East with a total area of 1.12 million $\mathrm{km}^{2}$ and possesses a wide range of geomorphic province with ecological and socio-cultural variations (MoA, 2000). It has a diverse ecosystem, ranging from humid forests and extensive wetlands in the west and south west to the desert of Afar depression in the northeast. The altitudinal range of the country varies from $110 \mathrm{~m}$ below sea level at dalol in Afar to 4620 m.a.s.l. at the highest peak of Ras Dejen (IBC, 2008). Unique geological formation of Ethiopia resulted in great geographical diversity which in turn resulted in the formation of diverse ecological conditions that helped to have rich biodiversity (Taye et al., 1999). Previous studies (e.g., Taye et al., 1999; Zerihun, 1999) justified that the richness in biodiversity is the reflection of 
diverse ecological settings, climate and topography in the country. Ethiopia is a country with diverse and many important biological resources (Edwards and Kelbessa, 1999). The flora of Ethiopia is very heterogeneous and it is estimated to contain around 6500-7000 species of higher plants, of which about 12-19\% are endemic (USAID, 2013). This rich diversity and endemism of the country is mainly related with the presence of its diverse ecological features.

Ethiopia has one of the largest forest resources in the horn of Africa. Ethiopia owns a total of 59.7 million ha covered by woody vegetation among which: $3.56 \%$ are high forest (about 4.07 million ha), $49 \%$ woodland (29.24 million ha) and $44.2 \%$ shrubland or bushland (26.4 million ha) and plantations cover estimated to 955,705 ha (WBISPP, 2004). About $95 \%$ of the total high forest of the country is located in three regions namely Oromiya, SNNP and Gambela regional states (Yitebitu and Eyob, 2014). Oromiya has the highest forest covers $(2,547,632 \mathrm{ha})$ which accounts $63 \%$ of the total forest resource followed by SNNP and Gambela. These states accounts about $19 \%(775,393 \mathrm{ha})$ and $13 \%(535,393 \mathrm{ha})$ of the total forest cover of the country respectively (Srinivasan, 2014). The Ethiopian forests provide a wide variety of wood and non- wood products such as honey, incense, medicinal plants, bamboo, foodstuffs, etc. They are socially and commercially significant to the livelihoods of rural households. Despite its significant importance, deforestation is sever and has a long history in Ethiopia, especially in the central and northern highlands where subsistence farming and settlements has been changing landscapes for millennia (Mulugeta and Habtemariam, 2014). Population increases have resulted in extensive forest clearing for agricultural use, overgrazing, and exploitation of existing forests for fuel wood, fodder, and construction materials (Badege, 2001). Currently, the remaining natural high forests of the country are mainly found in the southwest, which was remote and inaccessible until recently (WBISPP, 2004; Mulugeta and Habtemariam, 2014). Northern Ethiopia which was covered by forests is suffering from conditions caused by land degradation (EPA, 1998). In the northern highlands of Ethiopia, patchy remnants of old-aged Afromontane forests are found almost only around the Ethiopian Orthodox Tewahido Churches. Forests in most other areas have been completely destroyed and converted into farms and grazing lands over centuries (Bongers et al., 2006). Recently, Ethiopia has been taking measures to rehabilitate degraded forests and forest lands (Mulugeta and Habtemariam, 2014). High population growth and the associated everincreasing demand on natural forests for various forest products and agricultural land has put the remnant forest patches on the verge of disappearance (Bekele, 1994). Patches of natural forests in the highlands of Ethiopia can serve as seed sources for restoration of degraded areas, as points of reference for restoration activities, and for biodiversity conservation (Wassie et al., 2005; Wassie and Teketay, 2006). However, the persistence of the remnant forest patches and their indigenous species in many areas are threatened. Fragmentation and habitat loss could influence the structure and regeneration of these forests (Cabin et al., 2002). Human-induced disturbances strongly influence the regeneration success of woody species and, in turn, determine the vegetation structure and composition of forests (Cotler and Ortega-Larrocea, 2006). Tesfaye et al. (2002) noted significant pressure from disturbances such as intensive tree removal and grazing on forest affect its regeneration in the Ethiopian highlands. Large areas show severe land degradation and erosion (Darbyshire et al., 2003). Therefore, appropriate and immediate measures are required to maintain and restore the remaining natural forests. Studies on plant communities help to design appropriate conservation measures. Plant communities show spatial and temporal variations across landscapes. Examination of patterns of population structures could provide valuable information about their regeneration and recruitment status that could be further employed for devising conservation strategies (Demel Teketay, 2005).

The availability of accurate data on forest resources is an essential requirement for management and planning within the context of sustainable development (FAO, 2007). Assessments such as woody species diversity, composition, and structure and regeneration status are essential in understanding the extent of plant diversity in forest ecosystem. Knowledge of floristic composition and structure of forest resources is also useful in identifying important elements of plant diversity, protecting threatened and economically important species and monitoring the state of reference among others (Segawa and Nkuutu, 2006). Reduction in forest cover has a number of consequences including loss of biodiversity and instability of ecosystems and reduced availability of various wood and non-wood forest products and services (Alemu and Bluffstone, 2007). So far various research works have been done with the forest. However, information are limited on floristic composition and diversity of woody species of Gemechis district Forest. Thus, the aim of present study was to determine and document the floristic composition, structure and regeneration status of woody species of the forest at Gemechis district and identifying the important elements of plant diversity including endemic plants.

\section{Materials and methods}

\subsection{Description of The Study Area}

This study was conducted in Gemechis mountain forest, West Hararghe Zone of Oromia National Regional State, Ethiopia(Figure 1). Gemechis mountain forest is one of the remaining patches of forests in the region $(6.5 \mathrm{~km}$ far from the district town, Quni) and $332.5 \mathrm{~km}$ from Addis Ababa on the way to Harer. This forest is located 


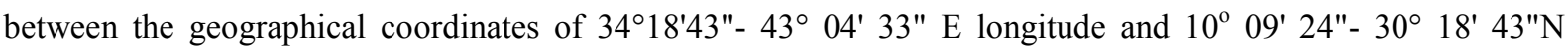
latitude. The altitude of this forest ranges between 2,118 and 3,017 meter above sea level (West Hararghe Forest and Wildlife protection Enterprise office, 2012). Gemechis forest is located on the mountain and highly dissected by river valleys and gorges that cut through the hills. The black, brown and red soils are the three dominant soil types constituting 55, 25 and 20\%, respectively (GDoANRO, 2012).

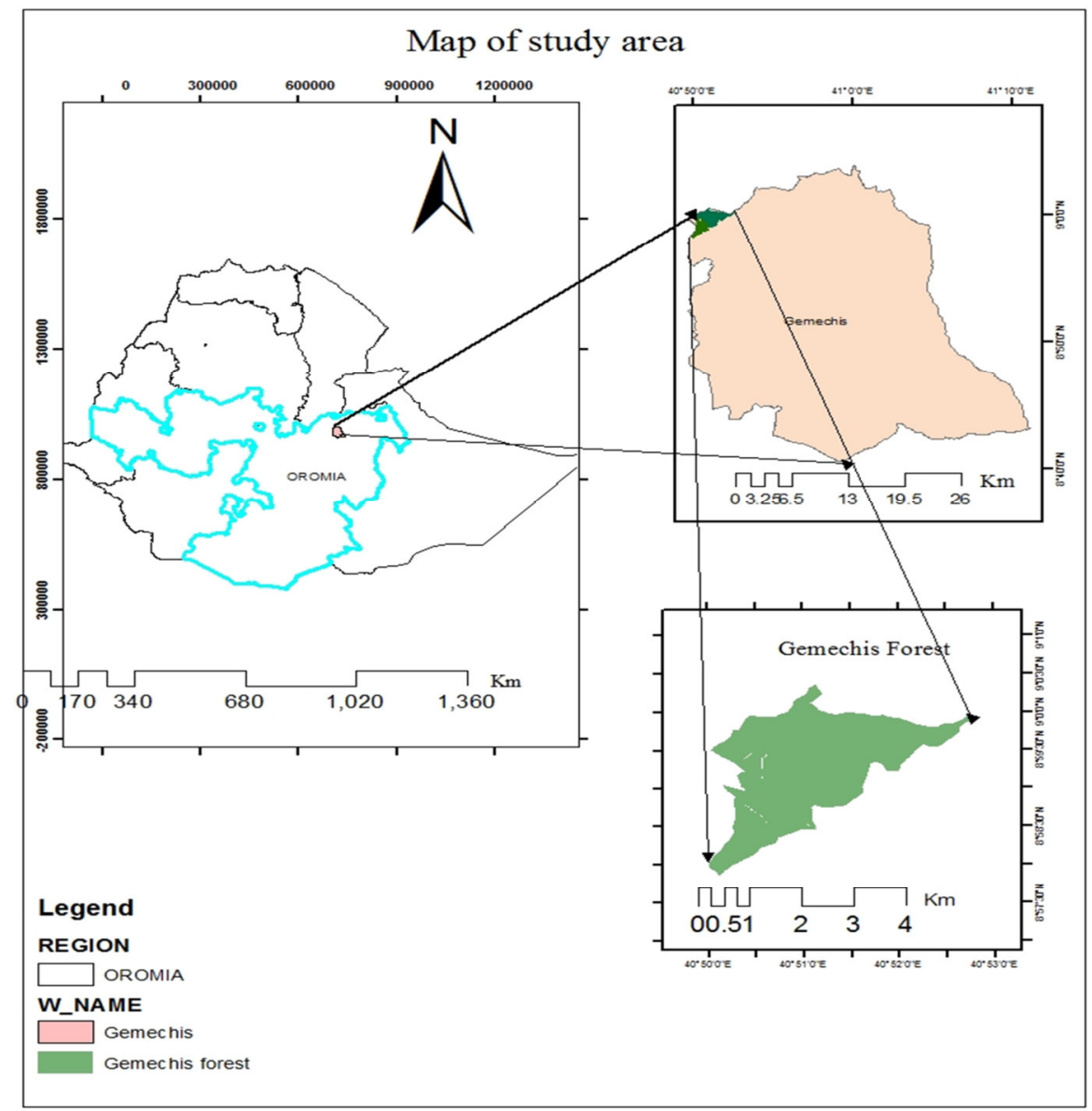

Figure 1. Location map of Gemechis Forest and Gemechis district areas Source: Own computation from GIS data, 2018

\subsection{Climate}

The district is found within 1300 to $3400 \mathrm{~m}$ above sea level (m.a.s.1). The minimum and maximum annual rainfall is $800 \mathrm{~mm}$ and $1200 \mathrm{~mm}$ with the average of $850 \mathrm{~mm}$. The district has bi-modal distribution in nature with small rains starting from March/April to May and the main rainy season extending from June to September/October. The minimum and maximum temperature $15^{\circ} \mathrm{C}$ and $30^{\circ} \mathrm{C}$ with the average temperature is $22^{\circ} \mathrm{C}$ (GDoANRO, 2016).

\subsection{Vegetation}

Dry Evergreen Montane forest is a very complex vegetation type occurring from $1500 \mathrm{~m}$ to $3200 \mathrm{~m}$ altitude, with average annual temperature and rainfall of 14-25 $\mathrm{C}^{\circ}$ and 700-1100 mm, respectively (Zerihun, 1999). The Gemechis forest belongs to this type of vegetation.Croton macrostachyus., Juniperus procera, Podocarpus falcatus, Vernonia amygdalina and Hagenia abysinica are some of the the spp. occuring. Plants such as Juniperus procera, Cupressus lusitanica, Eucalyptus camaldulensis, Hagenia abyssinica and Acacia saligna are some of the spp. introduced through plantation activities to enrich the vegetation (Western Hararghe Zone Forest and Wildlife protection Enterprise office, 2012). 


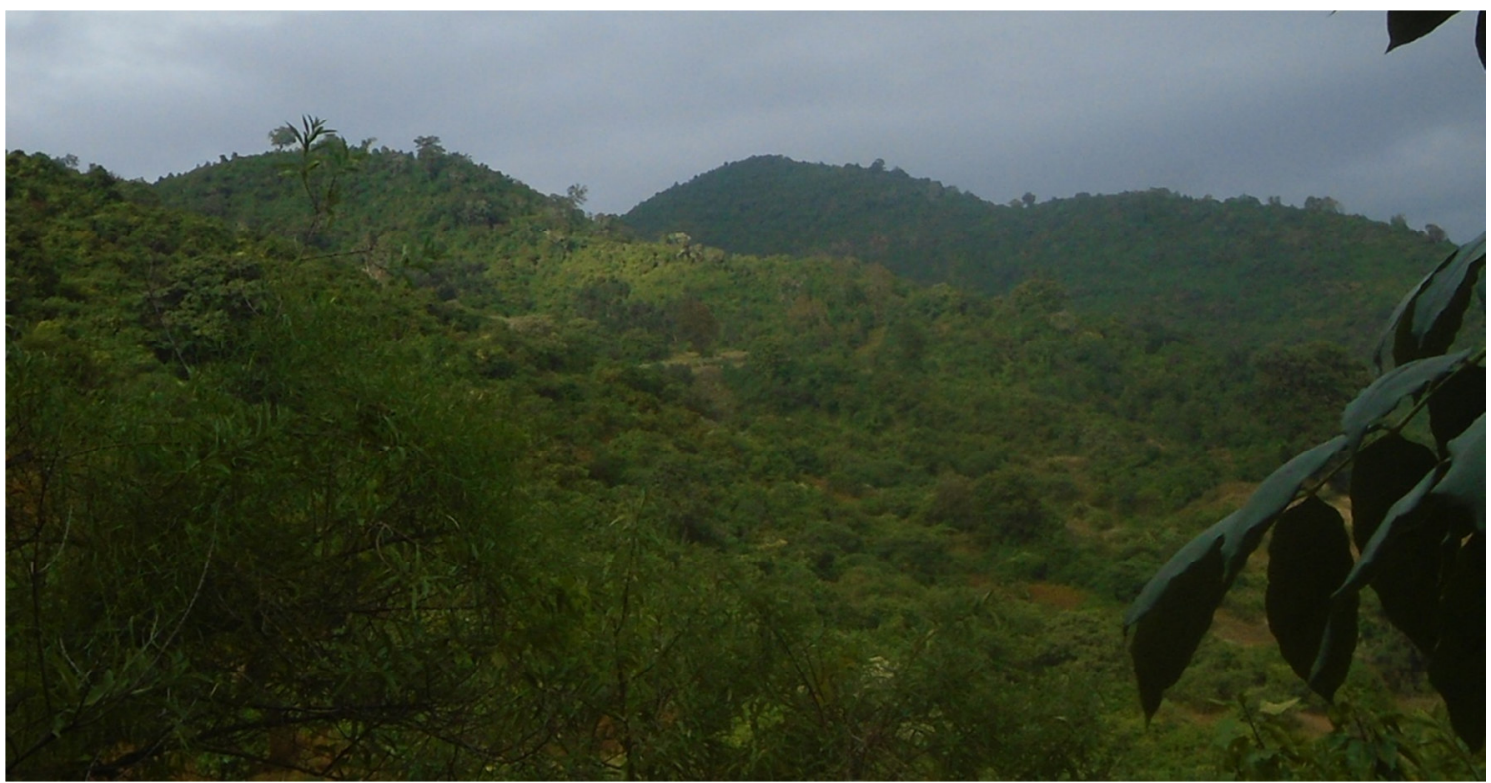

Figure 2. Overview of vegetation of Gemechis

\subsection{Reconnaissance Survey and Vegetation Data Collection}

Prior to actual vegetation data collection, reconnaissance survey was conducted in the study area from October 25-27 to obtain the general setting of the environment so as to determine the position, number and length of transects to be laid across the forest. The actual data was collected from November 06-20, 2017. Six transects, which are $300 \mathrm{~m}$ apart were laid systematically across the sample sites in altitudinal gradient with having different number of plots depending on the length of the transect lines. Fifty quadrats, $20 \mathrm{mX} 20 \mathrm{~m}\left(400 \mathrm{~m}^{2}\right)$ were established along the transects at every $50 \mathrm{~m}$ interval.

In each of the quadrat, all live woody species (WS), number of live individuals of all WS and diameter at breast height (DBH) of all WS (with DBH $>2 \mathrm{~cm}$ ), except juveniles (seedlings and sapling: height $<1.5 \mathrm{~m}$ ) were collected and all the plant species encountered in each sampled plot were recorded using both botanical and vernacular names. In the case of seedlings and coppices, the number of individuals of each species was counted and recorded in each quadrat. For this, 5 sub-plots of $5 \mathrm{~m} \mathrm{x} 5 \mathrm{~m}$ one at each corner and one at the center of the big plots were laid. A caliper was used to measure diameter at breath height $(\mathrm{DBH}=1.3 \mathrm{~m})$. For woody species that were branched at around the breast height, the DBH was measured separately and averaged. The woody species was preliminarily identified in the field by using the available literature (e.g. Flora of Ethiopia and Eritrea).The collected Voucher specimens of each WS were dried, pressed and identifed in Haramaya University.

\subsection{Data Analysis}

Species richness was determined from the total number of woody species recorded in sample plots.

The diversity of woody species was analyzed by using the Shannon-Wiener Diversity Index (Krebs, 1989; Magurran, 2004). The index takes into account the species richness and proportion of each species in all sampled quadrats of the study site. The value of Shannon diversity index usually found to fall between $1.5-3.5$ and rarely surpasses 4.5 (Magurran, 1988).

The Shannon diversity index is calculated from the formula:

$$
\mathrm{H}^{\prime}=-\sum_{i=1}^{s} P i \ln P i
$$

Where: $\mathrm{H}^{\prime}=$ Shannon-Wiener Diversity Index; $\Sigma=$ Summation symbol; $\mathrm{pi}=$ the proportion of

individuals or the abundance of $i t h$ species expressed as a proportional of total cover in the sample and $\ln =\log$ bases (natural logarithms).

Evenness or equitability, a measure of similarity of the abundances of the different woody species in the study site, was analyzed by using Shannon's Evenness or Equitability Index (Krebs, 1989; Magurran, 2004).

Equitability or evenness index was calculated using the following formula:

$$
\mathrm{E}=\mathrm{H}^{\prime} / \ln (\mathrm{S})=\mathrm{H}^{\prime} / \mathrm{Hmax}
$$

Where: $\mathrm{E}=$ Evenness; $\mathrm{H}^{\prime}=$ Shannon-Wiener Diversity Index; Hmax $=\ln \mathrm{S} ; \mathrm{S}=$ total number of species in the sample. The value of evenness index falls between 0 and 1 . The higher the value of evenness index, the more even the species is in their distribution within the given area.

Density of the woody species was calculated by converting the total number of individuals of each woody species encountered in all the quadrats and all transects used in the site to equivalent number per hectare.

The frequency was calculated as the proportion (\%) of the number of quadrats in which each woody species was 
recorded from the total number of quadrats in the site.

Dominance of the woody species, with diameter at breast height (DBH) of $>2 \mathrm{~cm}$, was determined from the space occupied by a species, usually its basal area. The total basal area of each woody species was converted to equivalent basal area per hectare (Kent and Coker, 1992).

Basal area was calculated by using the following formula.

$$
\mathrm{BA}=\Pi \mathrm{d} 2 / 4
$$

Where $\mathrm{BA}=$ Basal area in $\mathrm{m}^{2}$ per hectare

$\mathrm{d}=$ diameter at breast height

$$
\Pi=3.14
$$

Important value index (IVI), which indicates the relative ecological importance of a given woody species at a particular site (Kent and Coker, 1992), was determined from the summation of the relative values of density, frequency and dominance of each woody species.

Relative density was calculated as the percentage of the density of each species divided by the total stem number of all species ha ${ }^{-1}$.

Relative density $=\frac{\text { Total No of individuals species } A}{\text { Total } \text { No of individuals of all species }} \times 100$

Relative frequency of a species was computed as the ratio of the frequency of the species to the sum total of the frequency of all species in the study site.

$$
\text { Relative frequency }=\frac{\text { frequency of species } A}{\text { Frequency of all species }} \times 100
$$

Relative dominance was calculated as the percentage of the total basal area of a species out of the total basal areas of all species at the study site.

$$
\text { Relative dominance }=\frac{\text { Dominance of species } A}{\text { Dominance of all species }} \times 100
$$

The population structure of each of the woody species in the study site was assessed through histograms constructed by using the density of individuals of each species (Y-axis) categorized into ten diameters classes (X-axis) (Peters, 1996), i.e. $1=<2 \mathrm{~cm} ; 2=2-5 \mathrm{~cm} ; 3=5-10 \mathrm{~cm} ; 4=10-15 \mathrm{~cm} ; 5=15-20 \mathrm{~cm} ; 6=20-25$ $\mathrm{cm} ; 7=25-30 \mathrm{~cm} ; 8=30-35 ; 9=35-40 ; 10=>40 \mathrm{~cm}$. Then, based on the profile depicted in the population structures, the regeneration status of each woody species will be determined (Neelo et al., 2015).

3.5.1. Sorensen's similarity index

Sorensen's similarity index was computed to help comparison between species composition of other similar vegetations of the region. Sorensen's similarity index was computed using the following formula.

Where: $\mathrm{S}_{\mathrm{s}}=$ Sorensen's similarity coefficient

$$
\mathrm{S}_{\mathrm{s}}=\frac{2 a}{2 a+b+c}
$$

$\mathrm{a}=$ number of woody species common to Gemechis forest and other forest in comparison

$\mathrm{b}=$ number of woody species found only in Gemechis forest.

$\mathrm{c}=$ number of woody species found only in the forest in comparison with Gemechis forest.

\section{Results and Discussion}

\subsection{Floristic Composition}

A total of 51 woody species were identified and documented from the study area, and the identified species belong to 34 families and 50 genera (Table.1). Of the total species, trees constituted 33(64.7\%), whereas shrubs and lianas constituted $16(31.3 \%)$ and $2(3.92 \%)$, respectively. In terms of species number, family Rosaceae was the most diverse being represented by $5 \mathrm{spp}$. followed by Lamiaceae and Myrsinaceae each represented by $4 \mathrm{spp}$.; Asteraceae, Boraginaceae, Eurphorbiaceae and Sapindaceae each represented by 2 species. All the remaining families were represented by two or one species.

The Shannon-Wiener Diversity index $\left(\mathrm{H}^{\prime}\right)$ and evenness values of Gemechis forest were 3.04 and 0.77 , respectively (Appendix table1). The $H^{\prime}$ of this forest is within the value of Shannon diversity index for most vegetations, which usually falls between 1.5 and 3.5 (Magurran, 1988), and suggests that this forest is of good diversity. Moreover, comparison of the Shannon diversity index of Gemechis forest with other similar vegetations studied in Ethiopia e.g. Yemrehane Kirstos Church Forest with 39 species and $\mathrm{H}^{\prime}=2.88$ (Amanuel, 2016), Menagesha Suba Forest with 112 species and $H^{\prime}=2.57$ (Dinkissa, 2011) and Ylat forest with 60 spices and $H^{\prime}=2.94$ (Sisay, 2016) shows that Gemechis forest has more diversity relatively to these forests. However, Gemechis forest has high number of spp. than Yemrehane Kirstos Church Forest and less number of species than other similar vegetation including that of Chilimo with $90 \mathrm{spp}$. (Tamrat Bekele, 1993); Belete forest with 79 spp. (Kitessa Hundera and Tsegaye Gadissa, 2008); Hugumburda forest with 79 spp. (Ermias Aynekulu, 2011); Lammo Natural Forest with 54 woody species (Melese Bekele, 2016),dindin forest with 81 spp. (Simon SHibru and Girma Balcha ,2004), Denkero with 109 spp. (Abate Ayalew et al., 2006) and Senka meda with 139 spp. (Shambel,2010). This may be because of a series previous disturbance occurring in the area by local peoples. Loss of forest cover and biodiversity due to human-induced activities is a growing concern in many parts of the 
world (Feyera Senbeta and Demel Teketay, 2003).

Table 4. Woody plant species of the study site with their Mean density(MD),\% frequency, Diameter at breast height (DBH) incm and Mean basal area $\left(\mathrm{m}^{2} / \mathrm{ha}\right)$

\begin{tabular}{|c|c|c|c|c|c|c|c|c|}
\hline No. & Scientific Name & Family & Local Name & $\mathbf{H a}$ & MD & Freq. & DBH & MBA \\
\hline 1 & Allophylus rubifolius & Sapindaceae & Xaxesa & $\mathrm{T}$ & 80.5 & 36 & 19 & 0.70846 \\
\hline 2 & Argomuellera macrophyllab & Eurphorbiaceae & Tambo boyyee & $\mathrm{S}$ & 321 & 66 & 16.87 & 0.55865 \\
\hline 3 & Bercium gradiflorim (Lam.) PichSerm & Lamiaceae & Huruba & $\mathrm{T}$ & 5 & 4 & 22.38 & 0.98251 \\
\hline 4 & Bersama abyssinica Fres. & Melianthaceae & Qillisa & $\mathrm{T}$ & 372 & 80 & 20.08 & 0.7912 \\
\hline 5 & Brucea antidysenterica J.F.Mill. & Simaroubiaceae & Abaaloo & S & 10 & 8 & 21.9 & 0.94123 \\
\hline 6 & Canthium oligocarpum Hiern. & Rubiaceae & Wanta Fulas & $\mathrm{T}$ & 46 & 24 & 5.31 & 0.05527 \\
\hline 7 & Carissa spinarum $\mathrm{L}$. & Apocynaceae & Agamssaa & $\mathrm{L}$ & 67 & 10 & 2.87 & 0.01613 \\
\hline 8 & Celtis africana Burm. & Ulmaceae & Mataqoma & $\mathrm{S}$ & 15 & 2 & 10.75 & 0.22679 \\
\hline 9 & Clerodendrum myricoides (Hochst.)Vatke & Lamiaceae & Tiroo/Misirch & $\mathrm{S}$ & 3.5 & 4 & 14.87 & 0.43375 \\
\hline 10 & Cordia africana $\mathrm{Lam}$. & Boraginaceae & Wanzaa & $\mathrm{T}$ & 27.5 & 6 & 7.34 & 0.1056 \\
\hline 11 & Croton macrostachyus Del. & Euphorbiaceae & Bakanisa & $\mathrm{T}$ & 33 & 26 & 17.29 & 0.58679 \\
\hline 12 & Cupressus lusitanica Mill. & Cupressaceae & Bubisa & $\mathrm{T}$ & 22.5 & 18 & 19.61 & 0.75477 \\
\hline 13 & Dodonea angustifolia L. f. & Sapindaceae & Ittacha & $\mathrm{S}$ & 5 & 2 & 2.5 & 0.012 \\
\hline 14 & Dombeya torrida (J.F.Gmel)P.Bamps & Sterculiaceae & Danisa & $\mathrm{T}$ & 34.5 & 26 & 12.51 & 0.30705 \\
\hline 15 & Dovyalis caffra (Hook. f. \& Harv.) Hook. f. & Flacourtiaceae & Koshimi & $\mathrm{T}$ & 269.5 & 82 & 19.11 & 0.71646 \\
\hline 16 & Dracaena steudneri Engl & Dracaenaceae & Gaalee & $\mathrm{L}$ & 27.5 & 14 & 5.28 & 0.05465 \\
\hline 17 & Ehretia cymosa Thonn. & Boraginaceae & Ulagaa & $\mathrm{T}$ & 14 & 14 & 25.67 & 1.29268 \\
\hline 18 & Ekebergia capensis Sparrm & Meliaceae & Sombo & $\mathrm{T}$ & 4.5 & 6 & 8.92 & 0.15627 \\
\hline 19 & Embelia schimperi Vatke & Myrsinaceae & Hanqu & $\mathrm{T}$ & 80.5 & 36 & 15.29 & 0.45854 \\
\hline 20 & Ficus sur Forssk. & Moraceae & Harbuu & $\mathrm{T}$ & 13 & 2 & 23.13 & 1.05023 \\
\hline 21 & Hageniaia abyssinica (Bruce) J. F. Gmel. & Rosaceae & Heexo & $\mathrm{T}$ & 17 & 4 & 14.6 & 0.41833 \\
\hline 22 & Juniperus procera Hochst. ex Endle. & Cupressaceace & Gatira Habasha & $\mathrm{T}$ & 3 & 4 & 15 & 0.44156 \\
\hline 23 & Lepidotrichilia volkensii(Gürke) Leroy & Meliaceae & Halaba & $\mathrm{T}$ & 25.5 & 14 & 19.57 & 0.75155 \\
\hline 24 & Lippia adoensis var. adoensis Hochst. ex Walp & Verbenaceae & Sukee & S & 18.5 & 22 & 5 & 0.04906 \\
\hline 25 & Maesa lanceolata Forssk. & Myrsinaceae & Abbayi & $\mathrm{T}$ & 516 & 90 & 22.04 & 0.95294 \\
\hline 26 & Manilkara butugiChiov. & Sapotaceae & - & $\mathrm{T}$ & 1.5 & 2 & 27.15 & 1.4466 \\
\hline 27 & Maytenus sp. & Celastraceae & Qaxamme & $\mathrm{T}$ & 268 & 76 & 31.01 & 1.8866 \\
\hline 28 & Myrica salicifolia A. Rich. & Myricaceae & Borodo & $\mathrm{T}$ & 31 & 8 & 5.98 & 0.07012 \\
\hline 29 & Myrsine africana $\mathrm{L}$. & Myrsinaceae & Qacamo & S & 45 & 4 & 20.35 & 0.81272 \\
\hline 30 & Ocimum lamifolium Hochest ex.nees & Lamiaceae & Damakase & $\mathrm{S}$ & 21 & 20 & 7.4 & 0.10747 \\
\hline 31 & Olea europaea L. ssp. cuspidate(Wall. ex DC.) Cifferri & Oleaceae & Ejersa & $\mathrm{T}$ & 2 & 2 & 8.33 & 0.13628 \\
\hline 32 & Osyris quadripartitea Decn & Santalaceae & Waatoo & $\mathrm{T}$ & 66.5 & 12 & 6.69 & 0.08789 \\
\hline 33 & Pavetta abyssinica Fresen. & Rubiaceae & Hatawi & S & 16 & 2 & 11.52 & 0.26044 \\
\hline 34 & Phytolacca dodecandra L'Herit. & Phytolaccaceae & Endod & $\mathrm{S}$ & 17.5 & 10 & 7.33 & 0.10554 \\
\hline 35 & Pittosporum viridiflorum Sims & Pittosporaceae & Solee & $\mathrm{T}$ & 10 & 4 & 21.68 & 0.92242 \\
\hline 36 & Podocarpus falcatus (Thunb.) R. B. ex. Mirb & Podocarpaceae & Birbirsa & $\mathrm{T}$ & 7 & 8 & 39.5 & 3.06199 \\
\hline 37 & Premna schimperi Engl. & Lamiaceae & Urgeessa & $\mathrm{T}$ & 28.5 & 6 & 20.4 & 0.81671 \\
\hline 38 & Prunus africana(Hook.f.) Kalkm. & Rosaceae & Muka Guracha & $\mathrm{T}$ & 42.5 & 6 & 8.5 & 0.14179 \\
\hline 39 & Rhamnus prinoides L.Herit & Rhamnaceae & Garaba Gosh & $\mathrm{T}$ & 13 & 4 & 4.89 & 0.04701 \\
\hline 40 & Rhus vulgaris Meikle & Anacardiaceae & Imbis & $\mathrm{T}$ & 12 & 18 & 18.8 & 0.69363 \\
\hline 41 & Rosa abyssinica & Rosaceae & Qaqawwe & $\mathrm{S}$ & 37 & 22 & 15.1 & 0.44737 \\
\hline 42 & Rubus steudneri Schweing & Rosaceae & Enjorii & $\mathrm{S}$ & 17 & 8 & 16.08 & 0.50744 \\
\hline 43 & Rumex nervosus Vahl & Rosaceae & Dhangago & $\mathrm{S}$ & 21.5 & 4 & 14.64 & 0.42062 \\
\hline 44 & Rytigna neglecta (Hiern) Robyns & Polygonaceae & Mixoo & $\mathrm{T}$ & 421 & 86 & 23.47 & 1.08086 \\
\hline 45 & Schefflera abyssinica (Hochst. ex A.Rich.)Radlk & Araliaceae & Gatamee & $\mathrm{T}$ & 19.5 & 8 & 22.22 & 0.96923 \\
\hline 46 & Senna didymobotrya (Fresen.) Irwin \& Bar & Fabaceae & Ceeqa & $\mathrm{T}$ & 25.5 & 20 & 10.15 & 0.20233 \\
\hline 47 & Solanium incanum L. & Solanaceae & Hiddi & S & 22 & 12 & 9.55 & 0.17898 \\
\hline 48 & Teclea nobilis Del. & Rutaceae & Hadhessa & $\mathrm{T}$ & 75.5 & 32 & 28.83 & 1.63131 \\
\hline 49 & Vangueria apiculata $\mathrm{K}$. Schum. & Rubiaceae & Buruurii & $\mathrm{S}$ & 14.5 & 6 & 7.13 & 0.09986 \\
\hline No. & Scientific Name & Family & Local Name & $\mathrm{Ha}$ & MD & Freq. & DBH & MBA \\
\hline 50 & Vernonia amygdalina Del. & Asteraceae & Ibicha Guracha & $\mathrm{T}$ & 124 & 40 & 20.83 & 0.85139 \\
\hline 51 & $\begin{array}{l}\text { Vernonia urticifolia A. Rich. } \\
\text { Total }\end{array}$ & Asteraceae & Ibicha Adi & $S$ & $\begin{array}{l}39.5 \\
3430\end{array}$ & 26 & 12.85 & $\begin{array}{c}0.32415 \\
31.12\end{array}$ \\
\hline
\end{tabular}

*Ha=habit, MD=mean density, Freq=frequency, DBH=Diameter at breast height, $\mathbf{M B A}=$ =mean basal area

Analysis of the habit or growth forms of speciesrecorded from Gemechis Forest was performed Accordingly, the highest proportion (64.7\%) was Tree. This was followed by shrubs $(31.3 \%)$ and lianas $(3.92 \%)$ (Figure 3). 


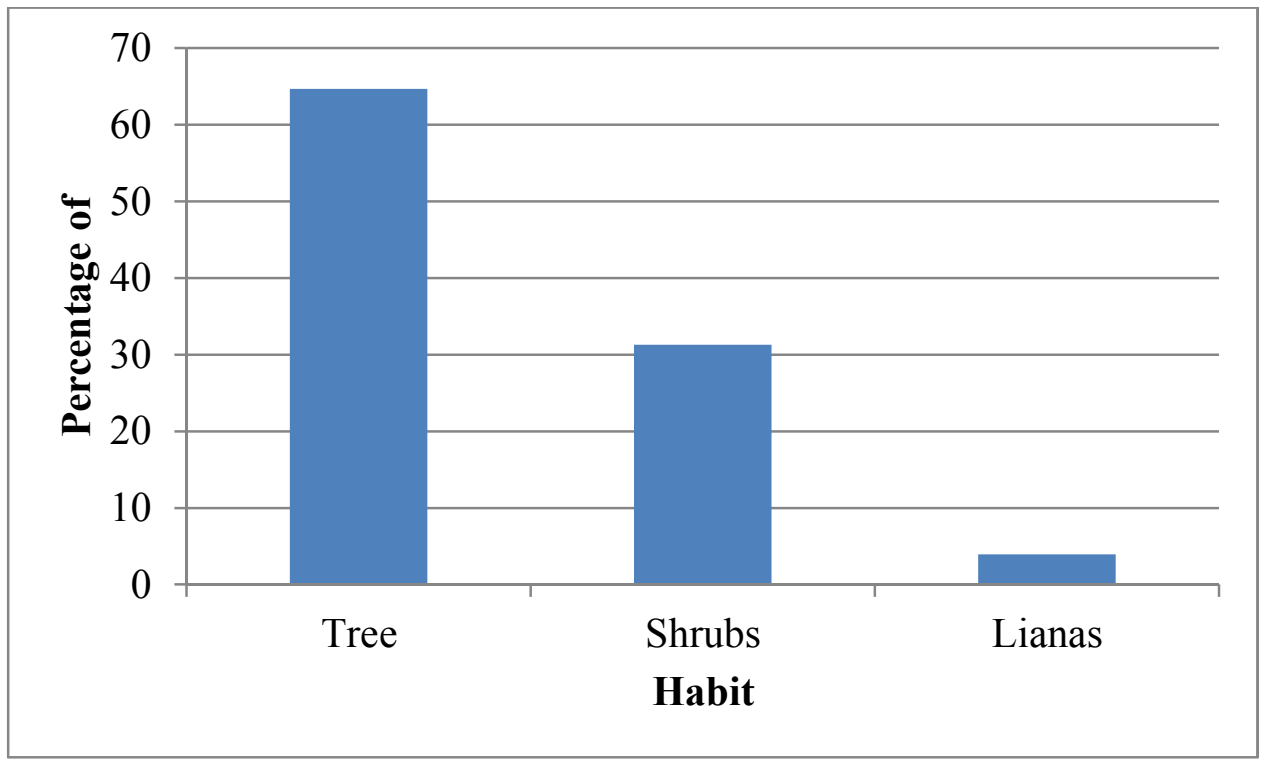

Figure 3: Habit of Plants in Gemechis Forest

Sorenson's coefficient of similarity was calculated to compare the similarity in family, genera and species composition of Gemechis natural forest vegetation with some other similar dry Afromontane forests of the country. From the result showed that Gemechis forest have highest similarity in species, genera and family with Dindin forest $(49.9 \%),(55.1 \%)$ and $(76.4 \%)$ respectively and followed by Belete forest for species $(36.8 \%)$ and genera(51.7\%) and Menagesha (74.6\%), Belete (71.4\% ) and Lemmo (59\%) for the families ( Table. 2) but least similarity in species and genera with lemmo forest. The probablity of high similarity between Gemechis forest and Dindin forests is that both forests are located close to each other, in west Hararghe, which have almost same altitudinal range. This might be according to Tamrat (1993) due to the geographic proximity of these forests to each other and similar human influences they have been exposed to.

Table 5. Comparison of the similarity in family, genera and species composition of Gemechis natural forest with some other similar dry Afromontane forests of the country. Where : $a=$ species common to the selected forests and Gemechis, $b=$ spp. unique to Gemechis, $c=s p p$ unique to selected forest and $\mathrm{Sc}=$ Sorenson's coefficient of similarity.

\begin{tabular}{llccccc}
\hline Taxa & Forest & Altitude(m) & a & b & c & Sc \% \\
\hline \multirow{5}{*}{ Species } & Menagesha Suba $^{1}$ & $2200-3385$ & 25 & 26 & 87 & 30.6 \\
& Belete forest $^{2}$ & $1850-2250$ & 23 & 28 & 51 & 36.8 \\
& Lammo Forest $^{3}$ & $2010-2484$ & 16 & 35 & 38 & 30.4 \\
& Dindin $^{4}$ & $2150-3000$ & 29 & 22 & 52 & 49.9 \\
\cline { 2 - 7 } Genera & Menagesha Suba & $2200-3385$ & 31 & 19 & 53 & 46.2 \\
& Belete forest & $1850-2250$ & 30 & 20 & 36 & 51.7 \\
\multirow{5}{*}{ Family } & Lammo Forest & $2010-2484$ & 21 & 29 & 24 & 44.2 \\
& Dindin & $2150-3000$ & 35 & 15 & 42 & 55.1 \\
& Menagesha Suba & $2200-3385$ & 32 & 2 & 19 & 74.6 \\
& Belete forest & $1850-2250$ & 25 & 7 & 13 & 71.4 \\
& Lammo Forest & $2010-2484$ & 18 & 14 & 11 & 59 \\
\hline
\end{tabular}

Sources: (Dinkissa Beche ${ }^{1}, 2011$ ), (Kitessa Hundera $\left.{ }^{2}, 2008\right)$, (Melese Bekele ${ }^{3}, 2016$ ) and (Simon SHibru and Girma Balcha ${ }^{4}, 2004$ )

\subsection{Density, Frequency and Dominance of Woody Plant Species}

The total density of all woody species recorded in Gemechis forest was 3430 individuals ha $^{-1}$ ( Table 1). The most dense individual species were Maesa lanceolata (516 individuals ha $\left.{ }^{-1}\right)$, Bersama abyssinica (372 individuals $\mathrm{ha}^{-1}$ ) Dovyalis caffra (269.5 individuals $\left.\mathrm{ha}^{-1}\right)$, Maytenus sp. (268 individuals ha $\left.{ }^{-1}\right)$, Vernonia amygdalina 124 individuals ha ${ }^{-1}$ (Table 1). The total densities of Gemechis forest of woody species of mediumsized individuals (DBH between 10 and $20 \mathrm{~cm}$ ) have large proportion than large sized individuals $(\mathrm{DBH}>20$ $\mathrm{cm})$. Comparison of ratio of woody species densities with DBH between $10 \mathrm{~cm}$ and $20 \mathrm{~cm}$ to density DBH $>20$ $\mathrm{cm}$ with other similar different vegetations of Ethiopia, e.g., (Chato, Gura Ferda, Denkoro, Alata-Bolale, Dindin and Gedo) showed that Gemechis forest have high ratio, which indicated that there are more dominance of 
lower and medium sized DBH class than the other similar forest.

Table 6. Comparison of woody species densities with DBH between $10 \mathrm{~cm}$ and $20 \mathrm{~cm}$, and $>20 \mathrm{~cm}$ of Gemechis Forest with other forests in Ethiopia with ratio of small sized to large sized of DBH class

\begin{tabular}{lcccl}
\hline Forest & $10<\mathrm{DBH}<20(\mathrm{X})$ & $\mathrm{DBH}>20(\mathrm{Y})$ & $\mathrm{X} / \mathrm{Y}$ & \multicolumn{1}{c}{ Source } \\
\hline Alata-Bolale & 365 & 219 & 1.67 & Woldeyohannes \\
& & & & $\begin{array}{l}\text { Enkossa (2008) } \\
\text { Birhanu Kebede(2010) } \\
\text { Gedo }\end{array}$ \\
Dindin & 432 & 464 & 1.79 & $\begin{array}{l}\text { Simon Shibru and Girma } \\
\text { Balcha (2004), }\end{array}$ \\
Chato & 333 & 219 & 1.99 & Feyera Abdena(2010) \\
Gura Ferda & 500 & 194 & 1.71 & Dereje Denu (2007), \\
Denkoro & 526 & 263 & 1.9 & Abate Ayalew et al., (2006) \\
Gemechis & 131 & 285 & 1.9 & \\
\hline
\end{tabular}

The frequency of $72.5 \%$ of the species of the study area was between $20 \%$ and $90 \%$, while $27.5 \%$ were below 20\% frequency. The most frequent woody species were Maesa lanceolata, Rytigna neglecta, Dovyalis caffra, Bersama abyssinica, Maytenus sp., Argomuellera macrophyllab, Vernonia amygdalina (Table 1). The species with the least occurrence include Ekebergia capensis, Myrsine africana, Rumex nervosus, Hagenia abyssinica, Rhamnus prinoides Pittosporumviridiflorum, Bercium gradiflorim, Clerodendrum myricoides, Juniperus procera,Celtis africana, Ficus sur., Olea europaea and Manilkara butugi (Table 1). Dominance of the woody species, with diameter at breast height $(\mathrm{DBH})$ of $>2 \mathrm{~cm}$ was determined from the space occupied by a species, usually its basal area. The total basal area of each woody species was converted to equivalent basal area per hectare. Total basal area of study area was $31.13 \mathrm{~m}^{2} / \mathrm{h}^{-1}$ ( Table 1). Comparison of the basal area of Gemechis forest with some other vegetations of the country showed that it was lower than Dindin $\left(49 \mathrm{~m}^{2} / \mathrm{ha}\right)$, Denkoro (45 $\mathrm{m}^{2} /$ ha), Menagesha-Suba $\left(158.68 \mathrm{~m}^{2} / \mathrm{ha}\right)$, Sanka Meda $\left(34.7 \mathrm{~m}^{2} / \mathrm{ha}\right)$ and Wof-Washa(64.32 (Table 4). This is may due to the trees belonging to higher DBH class in Gemechis Forest are fewer than the forest mentioned. Table 7. Comparison of the basal area of Gemechis forest with basal areas of other forests in Ethiopia in $\mathrm{m}^{2} \mathrm{ha}^{-1}$.

\begin{tabular}{lcl}
\hline Forests & $\mathrm{BA}\left(\mathrm{m}^{2} \mathrm{~h}^{-1}\right)$ & Source \\
\hline Dindin Forest & 49 & Simon SHibru and Girma Balcha (2004) \\
Denkoro & 45 & Abate Ayalew et al., (2006) \\
Menagesha Suba & 158.68 & Beche D.(2011) \\
Sanka Meda & 34.7 & Shambel Bantiwalu (2010) \\
Wof-Washa & 64.32 & Fisaha et al (2013) \\
Gemechis & 31.13 & \\
\hline
\end{tabular}

\subsection{Important Value Index (IVI)}

Data from relative density (RD), relative frequency (RF) and relative dominance (RDo) were used to calculate the importance value index (IVI) of the vegetation. It indicates the relative ecological importance of a given woody species at a particular site (Kent and Coker 1992). High species importance value index (SIV) is attributed to their high basal area, high relative frequency and high relative density. The greatest SIV reflects the degree of dominancy and abundance of a given species in relation to the other species in the area. It is also used for setting priority/ranking species management and conservation practices and helps to identify species as dominant or rare species (Kent and Coker, 1992).

A species having value of IVI greater than 5.00 can be considered dominant because of the relative ecological role it plays in the ecosystem (Fekadu Gurmessa, 2010). The dominant and ecologically most significant tree species in Gemechis forest on the basis of their IVI values were Maesa lanceolata (19.2), Rytigna neglecta (16.9), Maytenus sp. (15.9), Bersama abyssinica (14.2), Argomuellera (11.7), Dovyalis caffra (10.9), Teclea nobilis (9.24) and Vernonia amygdalina (7.3) (Table 5). These dominant species accounted for over $50.8 \%$ of the total IVI of the Gemechis Natural forest. Relatively, the higher IVI of these species is due to their high values of density, frequency and dominance. This suggests that these species are dominant species of Gemechis forest and play crucial role for the ecological functioning of the area. On the other hand, about twenty species each has less than 1\% IVI values, e.g., in descending order of IVI, Dombeya torrida, Osyris quadripartitea, Hageniaia abyssinica, Carissa spinarum, Juniperus procera, Clerodendrum myricoides, Prunus africana, Senna didymobotry Canthium oligocarpum, Pavetta abyssinica, Celtis africana, Solanium incanum, Cordia africana, Myrica salicifolia, Ocimum camifolium, Dracaena steudneri, Phytolacca dodecandra, Vangueria apiculata, Ekebergia capensis, Lippia adoensis, Olea europaea, Rhamnus prinoides. Such low abundance may be due to either adverse environmental conditions or random distribution of available resources in the forest (Miranda et al., 2002; cited in Feyera Senbeta et al., 2007). 
Table 8 . Woody plant species of the study site with their relative density(RD), relative frequency(RF), relative Dominance(RDo) and important value index(IVI).

\begin{tabular}{|c|c|c|c|c|c|}
\hline No. & $\begin{array}{r}\text { Scientific name } \\
\end{array}$ & RD & RF & RDo & IVI \\
\hline 1 & Allophylus rubifolius & 2.347 & 3.442 & 2.348 & 5.403 \\
\hline 2 & Argomuellera macrophyllab & 9.360 & 6.310 & 1.851 & 11.770 \\
\hline 3 & Bercium gradiflorim (Lam.) PichSerm & 0.146 & 0.382 & 3.256 & 4.384 \\
\hline 4 & Bersama abyssinica Fres. & 10.847 & 7.648 & 2.622 & 14.260 \\
\hline 5 & Brucea antidysenterica J.F.Mill. & 0.292 & 0.765 & 3.119 & 4.352 \\
\hline 6 & Canthium oligocarpum Hiern. & 1.341 & 2.294 & 0.183 & 1.580 \\
\hline 7 & Carissa spinarum L. & 1.954 & 0.956 & 0.053 & 2.023 \\
\hline 8 & Celtis africana Burm. & 0.437 & 0.191 & 0.752 & 1.416 \\
\hline 9 & Clerodendrum myricoides (Hochst.)Vatke & 0.102 & 0.382 & 1.437 & 1.973 \\
\hline 10 & Cordia africana Lam. & 0.802 & 0.574 & 0.35 & 1.257 \\
\hline 11 & Croton macrostachyus Del. & 0.962 & 2.486 & 1.945 & 3.494 \\
\hline 12 & Cupressus lusitanica Mill. & 0.656 & 1.721 & 2.501 & 3.912 \\
\hline 13 & Dodonea angustifolia L. f. & 0.146 & 0.191 & 3.341 & 4.495 \\
\hline 14 & Dombeya torrida (J.F.Gmel)P.Bamps & 1.006 & 2.486 & 1.018 & 2.331 \\
\hline 15 & Dovyalis caffra (Hook. f. \& Harv.) Hook. f. & 7.858 & 7.839 & 2.374 & 10.949 \\
\hline 16 & Dracaena steudneri Engl & 0.802 & 1.338 & 0.181 & 1.038 \\
\hline 17 & Ehretia cymosa Thonn. & 0.408 & 1.338 & 4.284 & 5.985 \\
\hline 18 & Ekebergia capensis Sparrm & 0.131 & 0.574 & 0.518 & 0.805 \\
\hline 19 & Embelia schimperi Vatke & 2.347 & 3.442 & 1.520 & 4.325 \\
\hline 20 & Ficus sur Forssk. & 0.379 & 0.191 & 3.480 & 4.910 \\
\hline 21 & Hageniaia abyssinica (Bruce) J. F. Gmel. & 0.496 & 0.382 & 1.386 & 2.300 \\
\hline 22 & Juniperus procera Hochst. ex Endle. & 0.087 & 0.382 & 1.463 & 1.992 \\
\hline 23 & Lepidotrichilia volkensii(Gürke) Leroy & 0.744 & 1.338 & 2.491 & 3.986 \\
\hline 24 & Lippia adoensis var. adoensis Hochst. ex Walp & 0.539 & 2.103 & 0.163 & 0.751 \\
\hline 25 & Maesa lanceolata Forssk. & 15.046 & 8.604 & 3.158 & 19.157 \\
\hline 26 & Manilkara butugiChiov. & 0.044 & 0.191 & 4.794 & 6.284 \\
\hline 27 & Maytenus sp. & 7.815 & 7.266 & 6.252 & 15.953 \\
\hline 28 & Myrica salicifolia A. Rich. & 0.904 & 0.765 & 0.232 & 1.206 \\
\hline 29 & Myrsine africana $\mathrm{L}$. & 1.312 & 0.382 & 2.693 & 4.818 \\
\hline 30 & Ocimum camifolium Hochest ex.nees & 0.612 & 1.912 & 0.356 & 1.076 \\
\hline 31 & Olea europaea L. ssp. cuspidate(Wall. ex DC.) Cifferri & 0.058 & 0.191 & 0.452 & 0.646 \\
\hline 32 & Osyris quadripartitea Decn & 1.939 & 1.147 & 0.291 & 2.318 \\
\hline 33 & Pavetta abyssinica Fresen. & 0.452 & 0.191 & 0.863 & 1.575 \\
\hline 34 & Phytolacca dodecandra L’Herit. & 0.510 & 0.956 & 0.350 & 0.966 \\
\hline 35 & Pittosporum viridiflorum Sims & 0.292 & 0.382 & 3.057 & 4.271 \\
\hline 36 & Podocarpus falcatus (Thunb.) R. B. ex. Mirb & 0.204 & 0.765 & 10.147 & 13.413 \\
\hline 37 & Premna schimperi Engl. & 0.831 & 0.574 & 2.706 & 4.354 \\
\hline 38 & Prunus africana(Hook.f.) Kalkm. & 1.239 & 0.574 & 0.470 & 1.851 \\
\hline 39 & Rhamnus prinoides L.Herit & 0.379 & 0.382 & 0.156 & 0.582 \\
\hline 40 & Rhus vulgaris Meikle & 0.350 & 1.721 & 2.299 & 3.342 \\
\hline 41 & Rosa abyssinica & 1.079 & 2.103 & 1.483 & 3.009 \\
\hline 42 & Rubus steudneri Schweing & 0.496 & 0.765 & 1.682 & 2.685 \\
\hline 43 & Rumex nervosus Vahl & 0.627 & 0.382 & 1.394 & 2.441 \\
\hline 44 & Rytigna neglecta (Hiern) Robyns & 12.276 & 8.222 & 3.582 & 16.938 \\
\hline 45 & Schefflera abyssinica (Hochst. ex A.Rich.)Radlk & 0.569 & 0.765 & 3.212 & 4.750 \\
\hline 46 & Senna didymobotrya (Fresen.) Irwin \& Bar & 0.744 & 1.912 & 0.671 & 1.616 \\
\hline 47 & Solanium incanum L. & 0.641 & 1.147 & 0.593 & 1.414 \\
\hline 48 & Teclea nobilis Del. & 2.201 & 3.059 & 5.406 & 9.239 \\
\hline 49 & Vangueria apiculata K. Schum. & 0.423 & 0.574 & 0.331 & 0.854 \\
\hline 50 & Vernonia amygdalina Del. & 3.616 & 3.824 & 2.821 & 7.288 \\
\hline 51 & Vernonia urticifolia A. Ric. & 1.152 & 2.486 & 1.074 & 2.550 \\
\hline
\end{tabular}

\subsection{Population Structure and Regeneration Status of Gemechis forest}

Population structure is the distribution of individuals of each species in arbitrarily diameter height size classes to provide the overall profile of species under study (Peter, 1996). Woody species of Gemechis forest were subdivided into $10 \mathrm{DBH}$ classes ( Fig. 3). The cummulative DBH class distribution of Gemechis forest showed that 
the number of individuals that fall in lower DBH classes were higher than their number at higher DBH classes (Fig. 3). This result shows that total number of woody species was found to decrease with increasing DBH, suggesting that seedlings and sapling were more in number than the mature/older woody species. This in turn shows that the vegetation of Gemechis forest was generally in a good regeneration status. From the population dynamics point of view, examination of patterns of species population structure could provide valuable information about their regeneration and/or recruitment status as well as viability status of the population that could further be employed for devising evidence-based conservation and management strategies (Demel Teketay, 2005; Abrham Abiyu et al., 2006).

Analysis of population structure of individual species selected based on their higher IVI showed two different DBH distribution patterns were recognized in most dominant Species of the study area (Figure 4a$\mathrm{j}$ ). The first pattern was described as normal $\mathrm{DBH}$ distribution patterns, that had more or less the inverted Jshaped histogram. This pattern indicates the exsistence of highest frequency in the lower DBH classes and gradually decreases towards the higher diameter class. Species with such pattern were Maesa lanceolata, Bersama abyssinica, Rytigna neglecta, Maytenus sp., Dovyalis caffra and Teclea nobilis. The second pattern was described as irregular distribution where no defined pattern will be observed when one goes across the DBH classes. This type of pattern could be the result of selective cutting of individual species by the local people for various purposes. Example of species with such pattern were Vernonia amygdalina, Allophylus rubifolius, Embelia schimperi, Argomuellera macrophyllab.

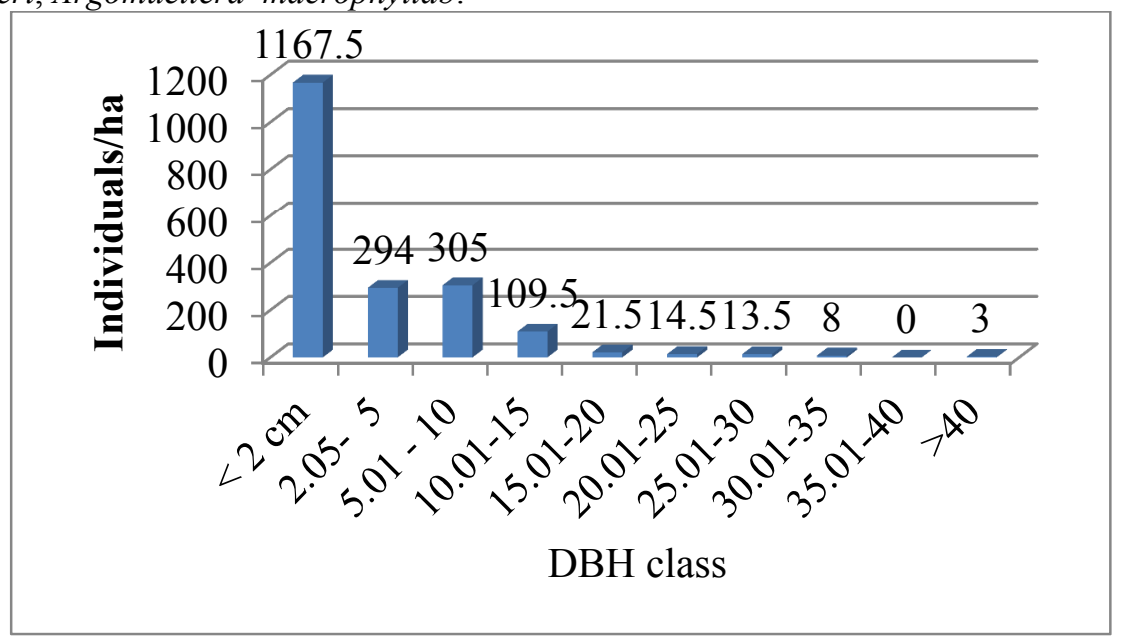

Figure 4. Cummulative DBH clss distribution of woody species of Gemechis forest
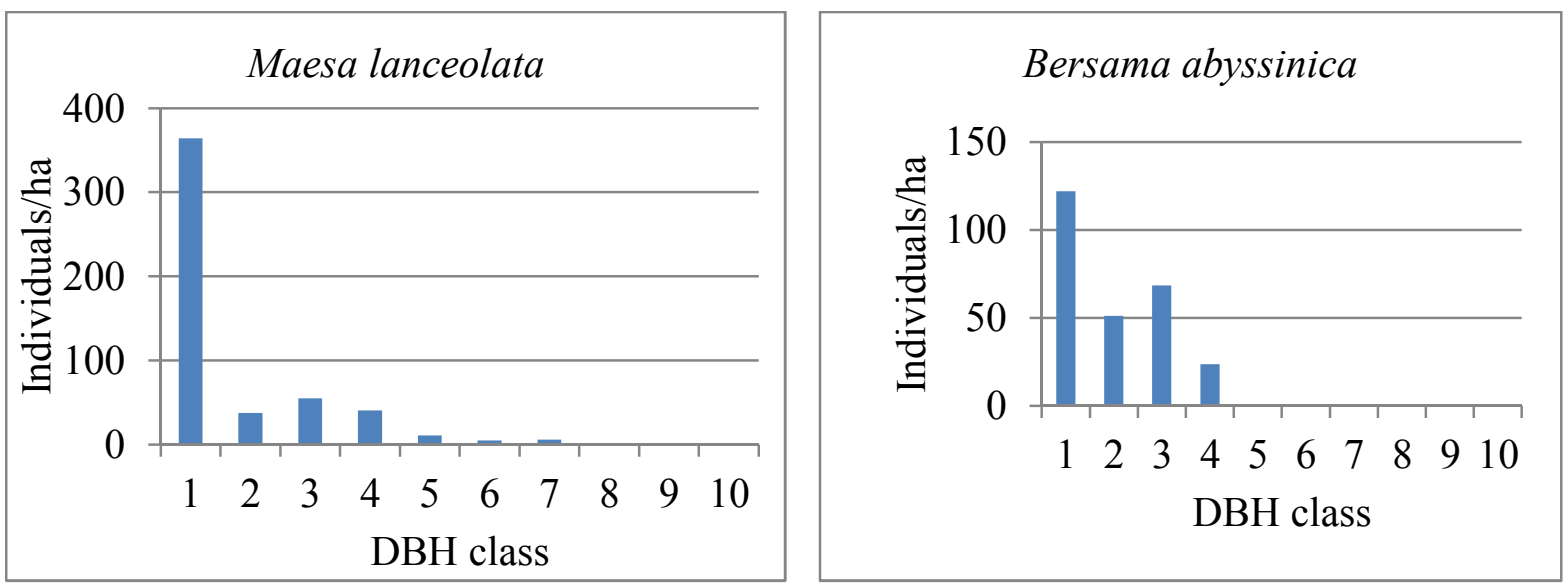

a)

b) 

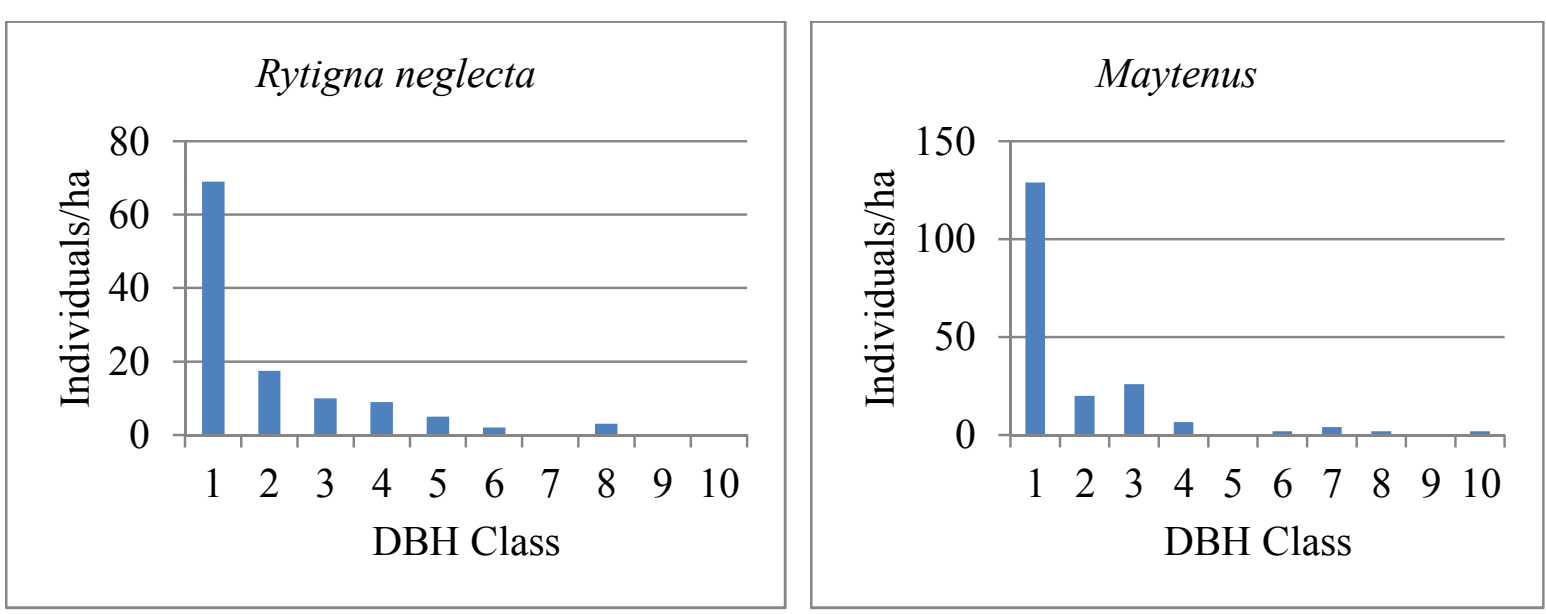

c)

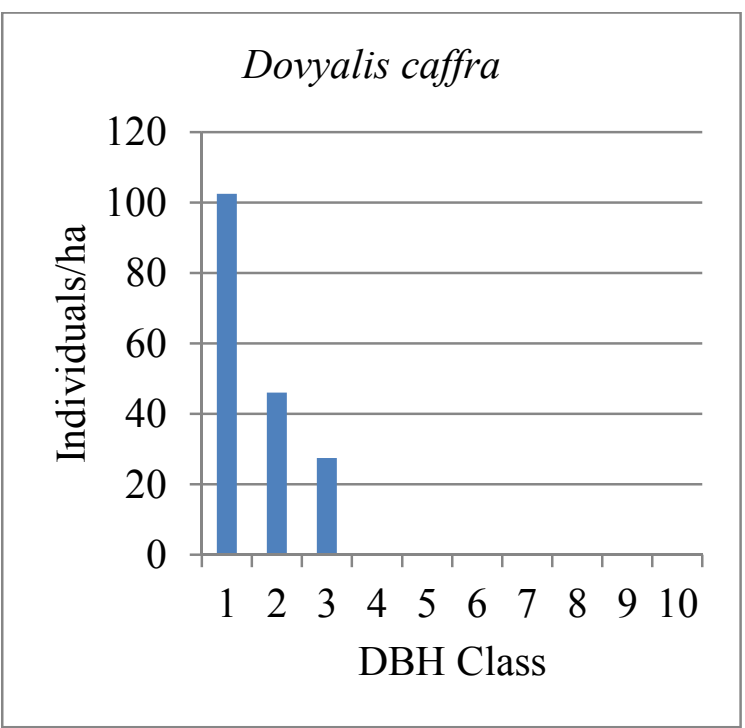

e)

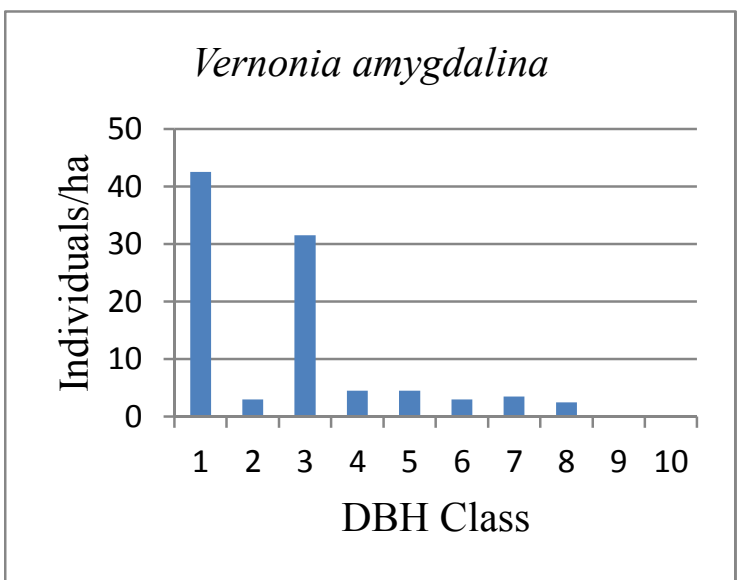

g) d)

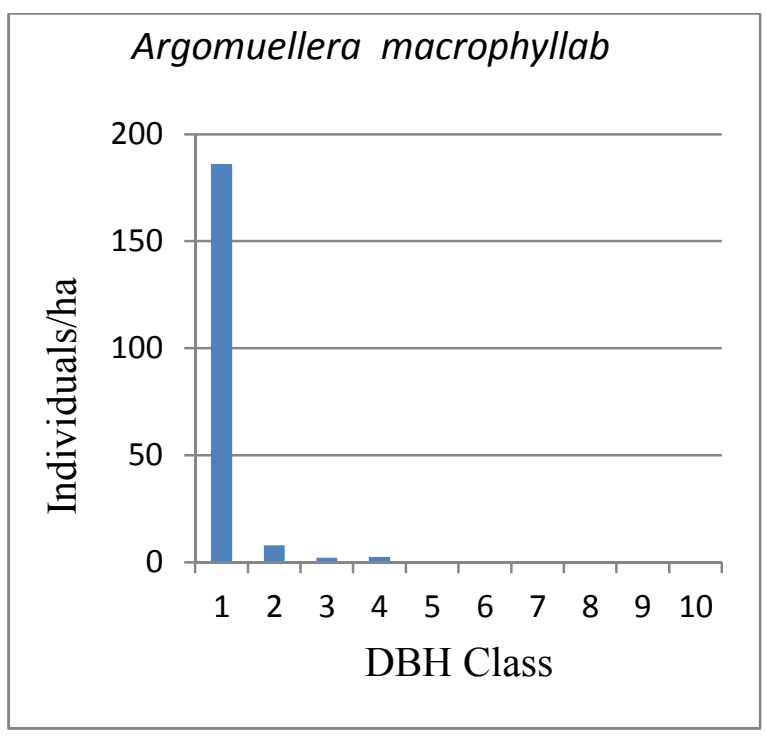

f

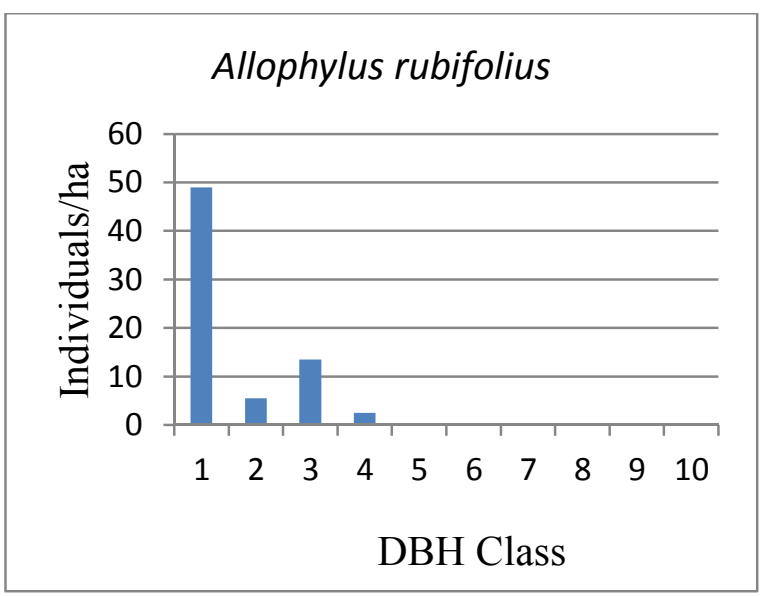

h) 


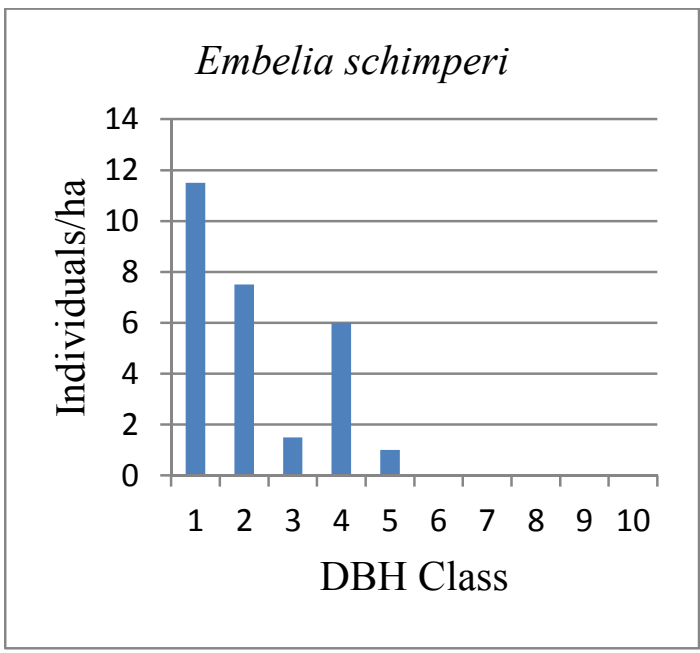

i)

Figure 5. DBH class distributions of some important woody species (having higher IVI values) in Gemechis forest.

\section{Conclusions}

The floristic composition, structure and regeneration of plant species is Gemechis Forest has been studied. The results of the study indicated that the forest had high species diversity with 51 woody species belonging to 50 genera and 34 families were found in Gemechis forest . Rosaceae ,Lamiaceae and Myrsinaceae significant contribution to the overall species composition of the Forest. Analysis of population structure of the most common species indicated that the majority of them showed a reversed J-shape with the exception of few species so that regeneration and recruitment are normal. The density of tree species in the forest decreases with increasing DBH class, which implied the predominance of small sized individuals in the lower classes than in the higher classes indicating good recruitment of the forest and rare occurrence of large individuals. This shows that the forest is in the secondary state of development. In conclusion, Gemechis forest has high species diversity and good overall regeneration status.

Based on the results of the study, the following recommendations were drawn.

$>$ Further study on soil seed bank, germination potential, seed rain quality and quantity should be carried out for species with few or no indiviuals of lower DBH to pin point the reason behind their poor regeneration

$>$ The present study was limited to diversity, structure of woody species and regeneration status. Therefore, further study should be conducted on distribution of plant species in relation to the environmental factors such as soil type and properties

$>$ Attention and priority should be given for conservation of those woody species with low IVI value

$>$ Raising awareness of local communities on the value of forest resources and ecological consequences of deforestation should be made

\section{References}

Alemu Mekonnen and Bluffstone, R. 2007. Lessons from economics and international Experience. Bigham, G., Bishop, R., Brody, M., Bromley, D., and Clark, E. 1995. Issues in ecosystem evaluation: Improving information for decision making. Ecological Economics, 14: 73-90.

Badege, B. 2001. Deforestation and land degradation in the Ethiopian highlands: A strategy for physical recovery. North African studies. 8(1):7-26.

Cabin, R.J., Weller, S.G., Lorence, D.H., Cordell S., Hadway, L.J. 2002. Effects of microsite, water, weeding, and direct seeding on the regeneration of native and alien species within a Hawaiian dry forest preserve. Biological Conservation, 104: 181-190.

Cotler H., Ortega-Larrocea, M.P. 2006. Effects of land use on soil erosion in a tropical dry forest ecosystem, Chamela watershed, Mexico. Catena, 65: 107-117.

Darbyshire, I., Lamb, H. and Umer, M. 2003. Forest clearance and regrowth in northern Ethiopia during the last 3000 years. The Holocene, 13:537-546.

Demel Teketay. 2005. Seed and Regeneration ecology in dry afromontane forests of Earth scan. Forest disturbance and succession. Journal of Tropical Ecology, 46 ((1): 46-64. of Ethiopia II.

Edwards, S. and Kelbessa, E. 1999. Indicators to determine the level of threat to tree species. In: Proceedings of 
Forest Genetic Resources Conservation: Principles, Strategies and Actions, (Eds S. Edwards, A. Demise, T. Bekele and H. Gunther). Institute of Biodiversity Conservation and Research with GTZ, Addis Ababa.

EPA (Environmental Protection Authority). 1998. Conservation Strategy of Ethiopia: executive summary., Addis Ababa, Ethiopia.

FAO (Food and Agricultural Organization of the United Nations). 2007. State of the World's Forests. Forestry Department, $144 \mathrm{p}$.

FAO (Food and Agriculture Organization). 2010. Progress towards Sustainable Forest Management; Global Forest Resources Assessment main report FAO-forestry paper 131-163.

IBC (Institute of Biodiversity Conservation). 2008. Ethiopia: Second Country Report on the state of PGRFA to FAO. Addis Ababa Institute of Biodiversity Conservation, Ababa, Ethiopia.

MOA (Ministry of Agriculture). 2000. Agro ecological Zonation of Ethiopia. Ministry of Agriculture, Addis Ababa, Ethiopia.

Segawa, P. Nkuutu, D.N. 2006. Diversity of vascular plants on Ssese Island in Lake Victory, Central Uganda. $A f$. J. Ecol., 44: 22 - 29.

Srinivasan, S. 2014. Extension of Deforestation in Ethiopia: A Review. EPRA International Journal of Economic and Business. 2(2):2347-9671.

Tesfaye, G., Teketay, D., Fetene, M. 2002. Regeneration of fourteen tree species in Harenna forest, southeastern Ethiopia. Flora, 197: 461-474.

Taye Bekele, Gunther Haase and Teshome Soromessa. 1999. Forest genetic resource of Ethiopia: status and proposed actions In: Forest Genetic Resources Conservation: Principles, strategies and action.

USAID/Ethiopia (United States Agency for International Development/ Ethiopia). 2013. Ethiopian Biodiversity and Tropical Forests 118/119 Assessment. http://pdf.usaid.gov/pdf_docs/PNADM939.pdf. Accessed February 2013.

Wassie, A., Teketay, D. and Powell, N. 2005. Church Forests in North Gonder Administrative Zone, Northern Ethiopia. Forests, Trees and Livelihoods, 15, 349-373.

WBISPP (Woody Biomass Inventory and Strategic Planning Project). 2004. A national strategic plan for the biomass energy sector. Addis Ababa

Yitebitu M and Eyobr T., 2014. Overview of REDD+ Process in Ethiopia. Ministry of Environment and Forest, Addis Ababa,Ethiopia.

Zerihun Woldu. 1999. Forests in the vegetation types of Ethiopia and their status geographical context. In: S. Edwards, Abebe Demissie, Taye Bekele and G. Haase (eds.), Forest genetic resource conservation: principles, strategies and processing of the national forest genetic resources conservation strategy development workshop, 21-22. June 1999; Institute of Biodiversity Conservation and Research (IBCR) and the German Technical Co-operation (GTZ); Addis Ababa, Ethiopia. 


\section{APPENDIX}

Table 1. Shannon-wiener(H) index and averge eveness value $(\mathrm{H}=$ habit/life form, $\mathrm{L}=$ lianas, pi = proportion of individual, $\mathrm{S}=$ shrub,)

\begin{tabular}{|c|c|c|c|c|c|c|c|c|c|}
\hline No. & $\begin{array}{l}\text { Scientific Name } \\
\end{array}$ & На & Seedling & Sapling & Mature & Total & $\mathrm{Pi}$ & Lnpi & Pilnpi \\
\hline 1 & Allophylus rubifolius & $\mathrm{T}$ & 30.5 & 28.5 & 21.5 & 80.5 & 0.023473 & -3.75191 & -0.08807 \\
\hline 2 & Argomuellera macrophyllab & $\mathrm{S}$ & 135.5 & 160 & 25.5 & 321 & 0.0936 & -2.36873 & -0.22171 \\
\hline 3 & Bercium gradiflorim (Lam.) PichSerm & $\mathrm{T}$ & 0 & 4 & 1 & 5 & 0.001458 & -6.53073 & -0.00952 \\
\hline 4 & Bersama abyssinica Fres. & $\mathrm{T}$ & 107 & 122 & 143 & 372 & 0.108471 & -2.22128 & -0.24094 \\
\hline 5 & Brucea antidysenterica J.F.Mill. & $\mathrm{S}$ & 5.5 & 3.5 & 1 & 10 & 0.002916 & -5.83758 & -0.01702 \\
\hline 6 & Canthium oligocarpum Hiern. & $\mathrm{T}$ & 4.5 & 18.5 & 23 & 46 & 0.013413 & -4.31153 & -0.05783 \\
\hline 7 & Carissa spinarum $\mathrm{L}$. & $\mathrm{L}$ & 50 & 9.5 & 7.5 & 67 & 0.019536 & -3.93548 & -0.07688 \\
\hline 8 & Celtisafricana & $\mathrm{S}$ & 12 & 2.5 & 0.5 & 15 & 0.004374 & -5.43212 & -0.02376 \\
\hline 9 & Clerodendrum myricoides & $\mathrm{S}$ & 0 & 2.5 & 1 & 3.5 & 0.001021 & -6.88741 & -0.00703 \\
\hline 10 & Cordia africana & $\mathrm{T}$ & 12.5 & 6.5 & 8.5 & 27.5 & 0.008019 & -4.82598 & -0.0387 \\
\hline 11 & Croton macrostachyus Del. & $\mathrm{T}$ & 12.5 & 14.5 & 6 & 33 & 0.009622 & -4.64366 & -0.04468 \\
\hline 12 & Cupressus lusitanica Mill. & $\mathrm{T}$ & 6.5 & 11.5 & 4.5 & 22.5 & 0.006561 & -5.02665 & -0.03298 \\
\hline 13 & Dodonea angustifolia L. f. & $\mathrm{S}$ & 3.5 & 0 & 1.5 & 5 & 0.001458 & -6.53073 & -0.00952 \\
\hline 14 & Dombeya torrida & $\mathrm{T}$ & 8.5 & 8 & 18 & 34.5 & 0.01006 & -4.59921 & -0.04627 \\
\hline 15 & Dovyalis caffra (Hook. f. \& Harv.) Hook. f. & $\mathrm{T}$ & 107 & 94.5 & 68 & 269.5 & 0.078583 & -2.5436 & -0.19988 \\
\hline 16 & Dracaena steudneri Engl & $\mathrm{L}$ & 16 & 5 & 6.5 & 27.5 & 0.008019 & -4.82598 & -0.0387 \\
\hline 17 & Ehretia cymosa Thonn. & $\mathrm{T}$ & 6.5 & 6.5 & 1 & 14 & 0.004082 & -5.50111 & -0.02246 \\
\hline 18 & Ekebergia capensis Sparrm & $\mathrm{T}$ & 1 & 2 & 1.5 & 4.5 & 0.001312 & -6.63609 & -0.00871 \\
\hline 19 & Embelia schimperi Vatke & $\mathrm{T}$ & 68 & 11.5 & 1 & 80.5 & 0.023473 & -3.75191 & -0.08807 \\
\hline 20 & Ficus sur Forssk. & $\mathrm{T}$ & 2 & 9.5 & 1.5 & 13 & 0.003791 & -5.57522 & -0.02113 \\
\hline 21 & Hageniaia abyssinica (Bruce) J. F. Gmel. & $\mathrm{T}$ & 11.5 & 4.5 & 1 & 17 & 0.004957 & -5.30696 & -0.02631 \\
\hline 22 & Juniperus procera Hochst. ex Endle. & $\mathrm{T}$ & 1.5 & 1 & 0.5 & 3 & 0.000875 & -7.04156 & -0.00616 \\
\hline 23 & Lepidotrichilia volkensii(Gürke) Leroy & $\mathrm{T}$ & 7 & 12 & 6.5 & 25.5 & 0.007435 & -4.90149 & -0.03644 \\
\hline 24 & Lippia adoensis var. adoensis Hochst. ex Walp & $\mathrm{S}$ & 8 & 10.5 & 0 & 18.5 & 0.005394 & -5.2224 & -0.02817 \\
\hline 25 & Maesa lanceolata Forssk. & $\mathrm{T}$ & 137.5 & 225 & 153.5 & 516 & 0.150459 & -1.89406 & -0.28498 \\
\hline 26 & Manilkara butugiChiov. & $\mathrm{T}$ & 0 & 1 & 0.5 & 1.5 & 0.000437 & -7.7347 & -0.00338 \\
\hline 27 & Maytenus $\mathrm{sp}$. & $\mathrm{T}$ & 80.5 & 125 & 62.5 & 268 & 0.078146 & -2.54918 & -0.19921 \\
\hline 28 & Myrica salicifolia A. Rich. & $\mathrm{T}$ & 27 & 2 & 2 & 31 & 0.009039 & -4.70618 & -0.04254 \\
\hline 29 & Myrsine africana & $\mathrm{S}$ & 33.5 & 9 & 2.5 & 45 & 0.013121 & -4.33351 & -0.05686 \\
\hline 30 & Ocimum camifolium Hochest ex.nees & $\mathrm{S}$ & 12.5 & 7.5 & 1 & 21 & 0.006123 & -5.09565 & -0.0312 \\
\hline 31 & Olea europaea L. ssp. cuspidate(Wall. ex DC.) Cifferri & $\mathrm{T}$ & 1.5 & 0 & 0.5 & 2 & 0.000583 & -7.44702 & -0.00434 \\
\hline 32 & Osyris quadripartitea Decn & $\mathrm{S}$ & 45 & 11.5 & 10 & 66.5 & 0.019391 & -3.94297 & -0.07646 \\
\hline 33 & Pavetta abyssinica & $\mathrm{S}$ & 10.5 & 5 & 0 & 15.5 & 0.00452 & -5.39933 & -0.0244 \\
\hline 34 & Phytolacca dodecandra L'Herit. & $\mathrm{S}$ & 11.5 & 4.5 & 1.5 & 17.5 & 0.005103 & -5.27797 & -0.02693 \\
\hline 35 & Pittosporum viridiflorum Sims & $\mathrm{T}$ & 6 & 2.5 & 1.5 & 10 & 0.002916 & -5.83758 & -0.01702 \\
\hline 36 & Podocarpus falcatus (Thunb.) R. B. ex. Mirb & $\mathrm{T}$ & 1 & 4 & 2 & 7 & 0.002041 & -6.19426 & -0.01264 \\
\hline 37 & Premna schimperi & $\mathrm{T}$ & 20 & 6 & 2.5 & 28.5 & 0.00831 & -4.79027 & -0.03981 \\
\hline 38 & Prunus africana & $\mathrm{T}$ & 29 & 7.5 & 6 & 42.5 & 0.012392 & -4.39067 & -0.05441 \\
\hline 39 & Rhamnus prinoides & $\mathrm{T}$ & 0 & 8.5 & 4.5 & 13 & 0.003791 & -5.57522 & -0.02113 \\
\hline 40 & Rhus vulgaris Meikle & $\mathrm{T}$ & 4 & 4.5 & 3.5 & 12 & 0.003499 & -5.65526 & -0.01979 \\
\hline 41 & Rosa abyssinica & $\mathrm{S}$ & 1.5 & 17.5 & 18 & 37 & 0.010789 & -4.52925 & -0.04886 \\
\hline 42 & Rubus steudneri Schweing & $\mathrm{S}$ & 10 & 4.5 & 2.5 & 17 & 0.004957 & -5.30696 & -0.02631 \\
\hline 43 & Rumex nervosus Vahl & $\mathrm{S}$ & 9.5 & 11.5 & 0.5 & 21.5 & 0.006269 & -5.07212 & -0.0318 \\
\hline 44 & Rytigna neglecta (Hiern) Robyns & $\mathrm{S}$ & 313 & 61.5 & 46.5 & 421 & 0.122758 & -2.09754 & -0.25749 \\
\hline 45 & Schefflera abyssinica (Hochst. ex A.Rich.)Radlk & $\mathrm{T}$ & 13 & 3.5 & 3 & 19.5 & 0.005686 & -5.16976 & -0.0294 \\
\hline 46 & Senna didymobotrya (Fresen.) Irwin \& Bar & $\mathrm{T}$ & 4 & 15 & 6.5 & 25.5 & 0.007435 & -4.90149 & -0.03644 \\
\hline 47 & Solanium incanum L. & $\mathrm{S}$ & 16 & 6 & 0 & 22 & 0.006415 & -5.04913 & -0.03239 \\
\hline 48 & Teclea nobilis Del. & $\mathrm{T}$ & 50 & 17.5 & 8 & 75.5 & 0.022015 & -3.81604 & -0.08401 \\
\hline 49 & Vangueria apiculata K. Schum & $\mathrm{S}$ & 4 & 9.5 & 1 & 14.5 & 0.004228 & -5.46602 & -0.02311 \\
\hline 50 & Vernonia amygdalina Del. & $\mathrm{T}$ & 29 & 42.5 & 52.5 & 124 & 0.036157 & -3.31989 & -0.12004 \\
\hline 51 & Vernonia urticifolia A. Rich. & $\mathrm{S}$ & 19.5 & 6.5 & 13.5 & 39.5 & 0.011518 & -4.46387 & -0.05141 \\
\hline & & & 1506 & 1167.5 & 756 & 3429.5 & 1 & -248.225 & 3.04732 \\
\hline
\end{tabular}

